\title{
ORIGINAL RESEARCH Young people and snowmobiling in northern Norway: accidents, injury prevention and safety strategies
}

\author{
G Mehus ${ }^{1}$, AG Mehus², S Germeten', N Henriksen ${ }^{1}$ \\ ${ }^{1}$ University of Tromso, The Arctic University of Norway, Norway \\ ${ }^{2}$ Hammerfest Traffic School, Norway
}

Submitted: 3 September 2015; Revised: 25 June 2016; Accepted: 1 September 2016; Published: 20 October 2016

Mehus G, Mehus AG, Germeten S, Henriksen N

Young people and snowmobiling in northern Norway: accidents, injury prevention and safety strategies Rural and Remote Health 16: 3713. (Online) 2016

Available: http://www.rrh.org.au

A B S T R A C T

Introduction: Snowmobiling among young people in Scandinavia frequently leads to accidents and injuries. Systematic studies of accidents exist, but few studies have addressed young drivers' experiences. The aim of this article is to reveal how young people experience and interpret accidents, and to outline a prevention strategy.

Methods: Thirty-one girls and 50 boys aged 16-23 years from secondary schools in Northern Norway and on Svalbard, a Norwegian archipelago in the Arctic Ocean, participated in 17 focus groups segregated by gender. A content analysis identified themes addressing the research questions.

Results: Participants described risk as being inherent to snowmobiling, and claimed that accidents followed from poor risk assessment, careless driving or mishaps. Evaluation of accidents and recommendations for preventive measures varied. Girls acknowledged the risks and wanted knowledge about outdoor life, navigation and external risks. Boys underestimated or downplayed the risks, and wanted knowledge about safety precautions while freeriding. Both genders were aware of how and why accidents occurred, and took precautions. Boys tended to challenge norms in ways that contradict the promotion of safe driving behaviour. Stories of internal justice regarding driving under the influence of alcohol occurred.

Conclusions: Adolescents are aware of how accidents occur and how to avoid them. Injury prevention strategies should include a general population strategy and a high-risk strategy targeted at extreme risk-seekers. Drivers, snowmobilers' organisations and the community should share local knowledge in an effort to define problem areas, set priorities and develop and implement preventive measures. Risk prevention should include preparation of safe tracks and focus on safety equipment and safe driving behaviour, but 
should also pay increased attention to the potential of strengthening normative regulation within peer groups regarding driving behaviour and mutual responsibility for preventing accidents.

Key words: accident prevention, adolescent, focus groups, injury prevention, Norway, off-road motor vehicles, young adult.

\section{Introduction}

This study concerns snowmobiling, accidents and injury prevention among adolescents in sparsely populated rural and remote areas of Northern Norway and on the islands of Svalbard, where there are long distances to hospitals, patchy cell phone coverage and long alert and response times in cases of accidents. The geographical area of this research project encompasses 82950 inhabitants living within a territory of $121600 \mathrm{~km}^{2}$, and includes approximately $6500 \mathrm{~km}$ of legal snowmobile tracks $^{1,2}$. Of the 76474 registered snowmobiles in Norway in December 2013, 30819 were located in Troms, Finnmark and on Svalbard ${ }^{3}$.

Snowmobiles were introduced to Scandinavia in the 1960s as a tool for reindeer herders. Use of the vehicle spread rapidly to the general population. The use of snowmobiles is important for recreation, socializing and outdoor activities among adolescents and young adults in rural Arctic areas both in Scandinavia and in North America. According to phenomenological studies among drivers, adolescents and young adults describe freedom, bonding within peer groups, being out in the countryside and the search for flow experiences as important motivations for snowmobiling ${ }^{4,5}$. The snowmobile is a powerful vehicle that requires knowledge, driving skills and awareness to avoid accidents and injuries. Moreover, advanced competence in outdoor and rural mountain life is required when travelling in Arctic areas.

Despite snowmobile training, legislation and planning of snowmobile tracks, avoidable accidents and deaths occur. In Western Finnmark, men aged 15-29 years suffered the most injuries, and most accidents occurred while driving off the trails $^{6}$. From 2002 to 2004, men aged 15-24 years sustained the greatest number of snowmobile accident injuries in Western Finnmark. High speed, difficult terrain and inadequate driving skills were the main causes of the accidents $^{7}$. On Svalbard, over a 5 -year period starting in March 1997, local men aged 20-29 years and tourists aged 30-39 years topped the injury statistics $^{8}$. A comparison between North American and Scandinavian injury statistics from small rural areas reveals some common denominators in the injury mechanisms and injury contexts. Research from North America and Scandinavia has reported excessive speeding, drivers' lack of experience, poor judgement, drunk driving and night driving as risk factors for accidents ${ }^{6-16}$. The latest updated research from Norway does not summarise data about accidents related to drinking and driving ${ }^{7}$.

Over the past 25 years snowmobile accidents have been analysed and discussed in Scandinavia, the USA and Canada in order to develop strategies for preventing accidents ${ }^{7,8,15,17-20}$. Reducing snowmobile injuries and deaths is a national health policy goal for the Norwegian government ${ }^{21}$. National legislation has made the use of helmets mandatory, and there are engine size restrictions for 16-18 year olds in Norway. A driving licence program, prescriptions for trail structures and speed limits are enforced. These are important measures at the legislative and structural levels aimed at creating safe contexts for driving. However, regulations should build upon paying close attention to individuals and peer groups in order to understand how the formation and practice of actual norms and driving habits as well as exposure to accidents affect individual attitudes to risk assessment and risk taking.

Knowledge about norms and behaviour requires having a dialogue with the groups in question in order to understand the cultural aspects of the activity, and using young people's 
own understanding of their activities as the starting point. Accident prevention should include dissemination of established knowledge of outdoor life and an area's snowmobiling patterns ${ }^{22}$.

Traditional health prevention strategies have been criticised for inefficiency with regard to the promotion of behaviour change in targeted populations ${ }^{23}$. Relying solely on a topdown strategy to implement expert knowledge may restrain diffusion of knowledge. To overcome this obstacle, WHO has recommended a strategy for health promotion employing bottom-up approaches based on decentralisation and user participation. This approach allows for the articulation of a given problem as perceived by those affected by the problem in question by incorporating users' own definitions into the knowledge base used for efforts aimed at behaviour change. A community-based, organised accident prevention approach requires that the parties involved develop their own agendas, goals and strategies. From an empowerment perspective, this implies authorisation and transfer of power and a way of strengthening people's knowledge $\mathrm{e}^{23}$. Furthermore, empowerment may stimulate and promote safe attitudes towards snowmobiling and involvement to reduce injuries.

The present article is the third publication from a $\mathrm{PhD}$ dissertation on the topic of young snowmobilers' experiences and perceptions of risks, accidents and preventive measures connected to a valued leisure time activity. It aims to reveal experiences of driving behaviour, accidents, injuries and risk interpretation, and to outline elements of a strategy for accident prevention in line with WHO strategies for target group involvement.

\section{Methods}

Between January and April 2008, the first author interviewed 81 adolescents and young adults in 8 out of the 12 secondary schools in Northern Norway and on Svalbard. The schools were included based on strategic criteria related to size (small, medium and large) and geographical distribution (inland and coastal areas) to secure participation of adolescents and young adults from across the entire geographical area.

The present study analyses young people's own perceptions of risks and preventive measures, and the underlying behavioural and structural factors emphasised by the informants. The analytical frame is social constructivist ${ }^{24}$ and interactionist $^{25}$, as it interprets aspects of the youths' understanding as it unfolds through the development and negotiation of norms within peer groups, and the actual driving behaviours in the presence of their peers. Peer groups exert considerable influence when it comes to formation of norms, attitudes and behaviour within this age group.

\section{Context and participants}

The focus group participants were aged between 16 and 23 years, and were included from school classes selected based on teachers' knowledge of the students' use of snowmobiles. The first author presented the research project and asked students who were active snowmobile drivers in their leisure time to volunteer to participate. Seventeen focus groups, segregated by gender, were formed. The number of participants varied between two and eight. There were 10 male groups with a total of 50 boys, and seven female groups with a total of 31 girls.

\section{Focus group interviews}

Focus group interviews allow the study of content, meaning, group members' purposes, thoughts, beliefs and arguments, and the interaction between group members ${ }^{26}$. The interviews followed a semi-structured approach with openended questions formulated based on available research and theoretical approaches. The main questions were 'How do you carry out risk assessment and communicate about risks?' and 'Tell me about your experience with accident situations.' Follow-up questions elaborated on topics regarding, for example, prevention of accidents, peer group discussions and drunk driving. The first author was a moderator in the focus groups, and the participants were encouraged to talk about 
and elaborate on experiences and perceptions in relation to snowmobiling, accidents and risk-taking.

\section{Analytic approach}

The results presented here were obtained using Graneheim and Lundman's ${ }^{27}$ content analysis method. Thirteen main topics and a number of subtopics emerged. All text from the interviews was included in the analysis (about 90750 words). The interviews were read several times from different perspectives with the aim of identifying meaning units ('the constellation of words that relates to the same central meaning ${ }^{27}$ ), themes and categories. The statements were subject to analysis and interpretation. Subtopics emerged and were organised by the following themes:

- reasons for accidents

- police surveillance focus as an injury prevention strategy

- $\quad$ topics for education purposes

- individual preparations as a safety strategy.

An example of the analysis appears in Table 1. Statements presented in this article underwent translation from Norwegian into English, and the translated text was checked for correctness through back-translations done by the first author. Co-authors read five of the transcribed full-length interviews, and themes and categories were developed and discussed between the authors until consensus was established.

Citations presented in the Results section are given a letter referring to the interview from which the text originates.

\section{Ethics approval}

The Norwegian Social Science Data Services approved the project (number 16985-2007, 2011), and the school principals gave permission for the interviews to take place. Students were informed that participation was voluntary and that they had the right to withdraw from the study without stating any reason. Confidentiality and anonymity were

guaranteed. Those who agreed to participate gave their consent.

\section{Results}

The stories revealed a marked difference between boys and girls when it came to perceptions of risks and narratives about accidents. Overall, boys were more experienced drivers, but they were also to a larger extent engaged in risky driving. They are more dedicated to and occupied with the activity ${ }^{4}$. The following sections present themes associated with luck or bad luck, descriptions of risks, accident narratives and preventive measures taken by participants. The themes were not present in all group interviews, but they are reported here to describe the overall picture of the subject matters that emerged in the groups.

\section{Luck and coincidence}

Some of the boys and girls stated that snowmobiling was an activity involving an ever-present risk of incidents, mishaps and accidents, and where luck was a significant factor. The following is a statement from one girl and two boys:

You think about it afterwards. At the moment you are playing
around; you are in the middle of it; things happen. You make
choices and everything goes very fast. Afterwards, when you
get home, you think: maybe I was extremely lucky out there. (P)

\section{Risks and accidents}

The participants gave a variety of descriptions of factors associated with the risk of accidents, with some variation in how serious they considered the risk factors to be. Table 2 gives an overview of factors, grouped into individual risk taking and external factors when driving on and off prepared tracks, respectively. 
Table 1: Example of subtopic preparation during analysis

\begin{tabular}{|c|c|c|c|c|}
\hline $\begin{array}{l}\text { Meaning units from } \\
\text { transcription }\end{array}$ & $\begin{array}{c}\text { Condensed } \\
\text { meaning unit }\end{array}$ & $\begin{array}{l}\text { Interpretation of the } \\
\text { underlying meaning }\end{array}$ & Subtopic & Main topic \\
\hline $\begin{array}{l}\text { There are often many maniacs out there, } \\
\text { day and night. They think they have } \\
\text { better driving skills than they actually } \\
\text { have, and drive like fools without } \\
\text { control. }\end{array}$ & $\begin{array}{l}\text { Maniacs think they } \\
\text { are good drivers, } \\
\text { but encountering } \\
\text { them is scary. }\end{array}$ & $\begin{array}{l}\text { The maniacs drive } \\
\text { beyond their control } \\
\text { both day and night. }\end{array}$ & $\begin{array}{l}\text { 'The maniacs'; night } \\
\text { driving. }\end{array}$ & $\begin{array}{l}\text { Specific target group } \\
\text { behaviours for police } \\
\text { surveillance }\end{array}$ \\
\hline $\begin{array}{l}\text { The police should co-operate across } \\
\text { municipalities and arrange planned } \\
\text { raids. They cannot tackle a drunk driver } \\
\text { in open terrain. He will drive to his } \\
\text { death while attempting to run away. }\end{array}$ & $\begin{array}{l}\text { Police have to } \\
\text { cooperate and be } \\
\text { prepared to tackle } \\
\text { drunk drivers who } \\
\text { will attempt to run } \\
\text { away. }\end{array}$ & $\begin{array}{l}\text { The police have to } \\
\text { develop a strategy for } \\
\text { tackling a defined } \\
\text { problem: drunk drivers } \\
\text { and running away. }\end{array}$ & $\begin{array}{l}\text { Drinking and driving. } \\
\text { Running away. }\end{array}$ & \\
\hline $\begin{array}{l}\text { I injured my back not too long ago. We } \\
\text { were three people on a snowmobile. All } \\
\text { of us were drunk and we tried to drive up } \\
\text { a steep hill. It was not a very good idea } \\
\text {... The next day, my back hurt like } \\
\text { crazy and I couldn't walk. }\end{array}$ & $\begin{array}{l}\text { Drunk and driving, } \\
\text { hurt his back. }\end{array}$ & $\begin{array}{l}\text { When he sobered up and } \\
\text { looked back, he } \\
\text { regretted. }\end{array}$ & $\begin{array}{l}\text { Drinking and driving } \\
\text { situation. }\end{array}$ & Reasons for accidents \\
\hline $\begin{array}{l}\text { I was a passenger and we just wanted to } \\
\text { drive a little bit away from the campsite } \\
\text { to get mobile phone access. Then, } \\
\text { suddenly, the snowmobile fell 4-5 } \\
\text { meters down a cliff. }\end{array}$ & $\begin{array}{l}\text { An unexpected } \\
\text { mishap that could } \\
\text { have been fatal, but } \\
\text { caused only } \\
\text { bruisings and shock. }\end{array}$ & $\begin{array}{l}\text { A short, unplanned trip } \\
\text { ended in a drop from a } \\
\text { cliff. }\end{array}$ & $\begin{array}{l}\text { Natural conditions; } \\
\text { inattentiveness. }\end{array}$ & \\
\hline $\begin{array}{l}\text { We always drive together in this area, } \\
\text { and tell our relatives where we are going } \\
\text { and when we are supposed to come back. }\end{array}$ & $\begin{array}{l}\text { Information to } \\
\text { relatives about } \\
\text { where they are and } \\
\text { when they will be } \\
\text { back is important in } \\
\text { rural areas. }\end{array}$ & $\begin{array}{l}\text { Important to others. Just } \\
\text { in case of a need for } \\
\text { search and rescue. Never } \\
\text { drive alone. }\end{array}$ & $\begin{array}{l}\text { Information to relatives } \\
\text { at home and never drive } \\
\text { alone. }\end{array}$ & $\begin{array}{l}\text { Individual and group } \\
\text { preparation as a safety } \\
\text { strategy }\end{array}$ \\
\hline $\begin{array}{l}\text { I ask others about driving conditions if } \\
\text { they have been out there, and I check the } \\
\text { weather forecast. }\end{array}$ & $\begin{array}{l}\text { Seeking information } \\
\text { about weather and } \\
\text { driving conditions. }\end{array}$ & $\begin{array}{l}\text { Information about } \\
\text { weather and driving } \\
\text { conditions is important. }\end{array}$ & Preparing for the trip. & \\
\hline
\end{tabular}

Individual risk taking: Examples of risk factors related to the individual driver were hazardous driving (such as speeding) and drunk driving. Drunk driving was a theme in 16 of the 17 interviews. However, only a few informants said that they had driven a snowmobile themselves while under the influence of alcohol. The interviews contain stories about accidents related to perceived 'drink-and-drive' and speeding situations:
I injured my back not too long ago. Three of us were on a snowmobile. All of us were drunk, and we tried to drive up a steep hill. It was not a very good idea. I fell off three times. The last time, everyone fell off the snowmobile, and it went straight ahead down the hill. We had to run after it. The day after, my back hurt like crazy and I couldn't walk (J). 
We were drunk and set off to drive across a lake. A boy much older than I was driving. I tried to hold on very tight when he speeded up to approximately $100-120 \mathrm{~km} / \mathrm{h}$. Then I could not hold on anymore. I fell off and hung on by the handle. When I fell, my feet went into the track and blocked it so I was locked in the track. The snowmobile stopped and they tried to pull me out, but were not able to. The driver had to put it in reverse to get my feet out. I could not feel my feet and was just screaming. I did not let them call for help. The following day, when I began to sober up, I had insanely bad pains everywhere. Then we drove home and I called the emergency services and asked for help. They thought I had a femoral fracture, but I did not. Just luck! Afterwards, when I told my parents about it, they said that they hoped I had learned a lesson. Nevertheless, I will definitely do it again. Next time I will just have to hold on better! (C)

These two narratives show that some young people put themselves in hazardous situations while under the influence of alcohol, where the balance between good luck and bad luck is fragile. They take potentially life-endangering risks, and the second story reveals a willingness to repeat the risktaking behaviour with the only precaution being clinging more tightly to the snowmobile. Most stories, however, described careless driving and insufficient attention. One boy had been a passenger during a road crossing when the snowmobile crashed into a car because the driver did not see the car coming. Another accident occurred when the driver drove off a cliff of which he was unaware and crushed his helmet against the snowmobile. Here is yet another story involving a mishap:

I was a passenger and suddenly we just wanted to drive a little bit away from the campsite to get mobile phone access. Then, suddenly, the snowmobile fell 4-5 meters off a cliff. We were not wearing helmets, because it was not a long trip. There I learned that it is always important to wear a helmet. (J)

Playing while snowmobiling also resulted in injuries:

One of the first times I was out snowmobiling I broke my leg. We were having fun, playing and stuff. I jumped off the snowmobile while it was moving. Then it was not funny anymore when I got my leg caught under the sledge and snap! The leg fractured, right through. However, I didn't think that I should not have done this, or that it was stupid. It was more like: Ah, I wouldn't be able to snowmobile for a while now, just when all the other boys were planning a weekend trip to a mountain cabin nearby. And I could not join them. This was the worst thing for me! (A)

External risk conditions: Bad weather conditions constituted another uncontrollable risk that could present itself during ordinary trips:

\begin{abstract}
The weather is the worst thing. Last winter I drove in horrible weather. You could not see a thing! All I could do was to follow the rear light of the snowmobile in front of me. We drove four snowmobiles in a line. It was as bad as that. We were driving for three hours and never saw the trail. Just think - dear God! Then we saw some trail markers. We could hardly see them: just occasionally you could see one. (H)
\end{abstract}

Open waterholes were hidden dangers that could appear on legal, well-prepared tracks:

My dad and I were driving on the frozen river when we discovered a hole in the ice. We marked the hole to make sure no other snowmobilers would run into it. My dad fixed it, and when he turned back I fell into another hole. He grabbed me and pulled me up before I went under the ice in the river flow. It was scary: I still remember it very well. (K)

The narratives just presented reveal an awareness of inherent risks connected to snowmobiling, as well as risks arising from careless driving and even dangerous situations arising when the intention was to prevent accidents. The stories indicate shock, battered bodies, fractures, concussions, bruising and pain as the results of accidents. The responses to the accidents vary from positive lessons learned regarding the importance of wearing a helmet to negligent attitudes where the most painful aspect of the accident for the person involved was not being able to participate in subsequent peer group activities. 
Table 2: Risk factors identified by study participants

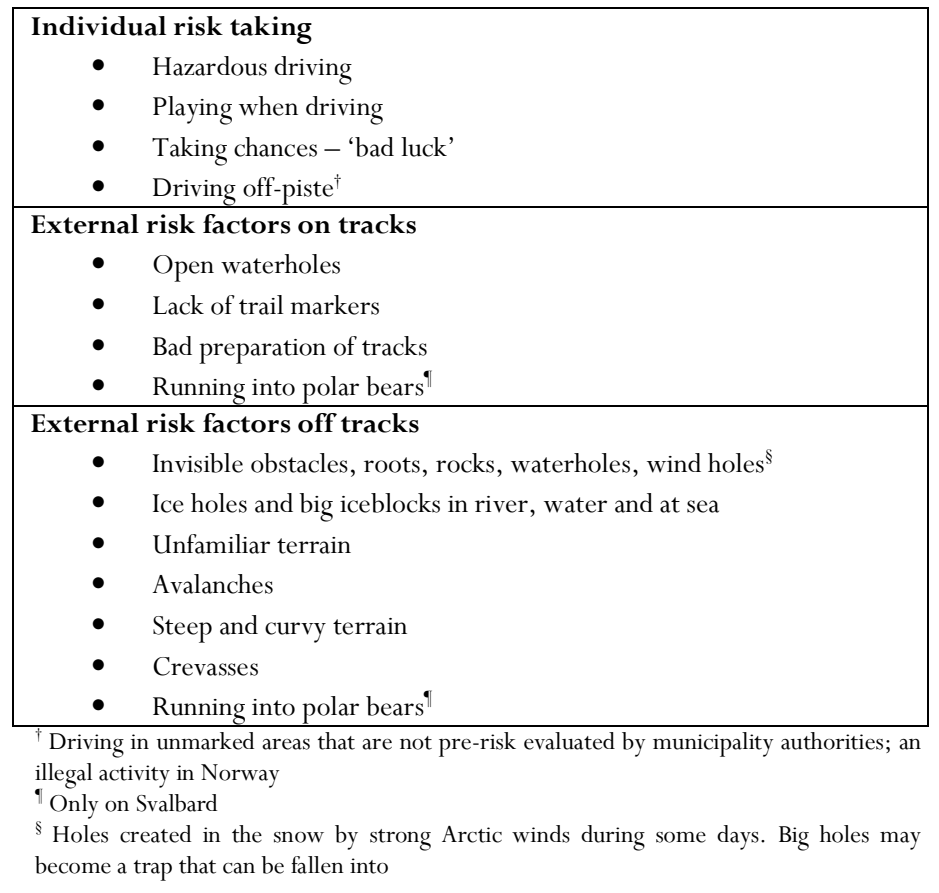

'The maniacs': Through descriptions of driving behaviour in the interviews, both boys and girls introduced a new term for a specific group of drivers, 'the maniacs', who constituted an unpredictable external source of risk. One informant said:

I am afraid of crashing! On narrow tracks, you can always meet a maniac. They are speeding, driving on the wrong side; they come from tracks that do not exist. They are not able to see if they might smash into other snowmobilers. (O)

Both boys and girls said this was a phenomenon to be aware of when snowmobiling. One girl said she did not dare to drive at night for fear of being run down by a 'maniac', especially one who was drunk. Many of the research participants indicated that they did not want to qualify as a 'maniac', and they denied engaging in the kinds of behaviour that characterised the 'maniacs'.

\section{Preventive measures}

The focus group participants identified a variety of preventive measures they would take prior to and during trips, and suggested new measures to control risks (Table 3).

One of the boys sarcastically stated that the only way to completely prevent accidents was 'to sell the snowmobile and lie on the couch for a year'. However, informants in all focus groups stated that they took precautions against external dangers, especially on long trips. Preparing for long-distance snowmobile trips involved having the necessary equipment, enough fuel, a well-maintained snowmobile, and being together in peer groups. The interviewees said that the degree of preparation depended on the distance and amount of time they would be away. Some boys and girls said they drove carefully and did not take any risks. Ensuring that they had enough clothes was another important precaution. 
With regard to whether some conditions were especially risky, one respondent stated:

$$
\text { Yes, if there is a lot of surface water and bad weather }
$$$$
\text { conditions. (H) }
$$

Focus group participants on the Svalbard archipelago gave more reasons for not driving alone than their peers in mainland Norway. They identified the lack of marked tracks, the presence of polar bears, long distances, rapidly shifting weather conditions and patchy or lacking cell phone coverage as particularly challenging in this polar region. Both boys and girls on Svalbard stated that they were aware of avalanches, polar bears, wind holes (created in the snow by strong Arctic whirlwinds) and crevasses. One of the girls described how they prepared for trips:

You just have to check out in advance and not go on trips alone. We always take someone with us who has a GPS and information. We drive on tracks that people have driven on before and ask them what it is like to drive there. (P)

A special challenge for snowmobilers on Svalbard is the danger of polar bear attacks. Bringing weapons along is therefore mandatory in this area.

There were also statements about strategies for preventing drunk driving, such as stopping friends from driving by taking their keys, inviting them to sit on the back seat, or saying that 'everybody is staying here at this party' to prevent them from leaving.

In order to be better at assessing risks, and to be better prepared for injuries and accidents, some girls said that they wanted to attend an extended first-aid course directly related to snowmobile driving. They also wanted to learn more about outdoor life, how to evaluate the risk of avalanches, how to do search and rescue (SAR), and how to drive in challenging terrain. Learning sessions should be offered for free, they said. Many boys stated that they had sufficient knowledge of outdoor life and related dangers. Some of them had participated in extended courses on first aid and SAR operations in avalanches, and other boys wanted more training for these situations. Some boys wanted defined recreational areas for practising and having fun. This involved challenging driving techniques such as jumping, climbing, wheeling and balancing on one ski.

A request for law enforcement: More girls want police surveillance because police presence helps reduce undesirable driving behaviour. Few boys discussed this theme. A girl stated:

The police should co-operate across municipalities and arrange planned raids. They cannot tackle a drunk driver in open terrain. He will drive to his death while attempting to run away. We get together in snow castles and have parties with 15-20 people. If the police were on surveillance from a distance, they could stop people who drive away from these castles to urinate. After an hour, they would have picked up many drunk drivers! Alternatively, they could show up around the castles wearing reflective vests: that would be preventive. No one would drive then. $(O)$

This indicates that both boys and girls hold parties at campsites. Driving after consuming alcohol appears to be quite common for some young people in this context, and some drivers seem willing to take extended risks to escape from police controls. Girls welcomed extended police surveillance. They stated that police presence in the mountains was necessary to control the 'maniacs'. They wanted police surveillance especially off track, at night and to catch drunk drivers. Generally, informants in this study maintained that the 'maniac' group caused a major proportion of all accidents.

\section{Discussion}

The narratives presented in this study stem from research participants' self-reported data and are not verified by observations. However, some major themes from different narratives appear consistently across the focus groups, and show that some accidents resulted from risk seeking, playing, 
mishaps and poor risk assessment. The descriptions of accidents in the narratives concern accident contexts that do not differ significantly from those reported in the accident register in Western Finnmark: high speed, difficult terrain and incorrect operation of a snowmobile ${ }^{7}$. Research from both Sweden and North America has indicated that night driving and fatal accidents are often associated with alcohol ${ }^{14-}$ 16. Numerous statements in the authors' data indicate that alcohol consumption may be frequent among some groups, and that drunk driving is associated with accidents in some cases. The study data do not permit an estimation of the true prevalence of this phenomenon.

Some informants made few reflections regarding the cause of the accidents, and tended to subsume the accidents and avoidance of accidents under the rubrics of 'bad luck' or 'good luck', respectively.

Overall, girls seemed to pay greater attention to risk compared to boys, and they took more safety precautions and engaged in less risky driving than the boys. The boys were more experienced drivers, and often took considerable risks while playing with the snowmobile. The desire to play seemed to overshadow their awareness of the inherent risks in snowmobiling, and their suggestions for bringing these kinds of activities into safer forms involved designating specific areas for excessive driving; that is, risky driving under some kind of surveillance. The girls wanted safety courses and more police surveillance.

The stories revealed an interesting internal peer group practice when it comes to regulating drunk driving: the group would prevent potential drunk drivers from driving, either physically or by using group pressure to stop them from leaving parties on a snowmobile after consuming alcohol. This is probably a practice with potentially powerful effects within relatively stable networks of adolescents.

Improving the quality of individual and group risk evaluation based on knowledge of snowmobile driving and local outdoor life is important to reduce the number of accidents and risk situations. One target group for prevention of accidents and mishaps is the 'maniacs'. This is not necessarily a uniform group, as driving with excessive risk might have different dispositional and behavioural motivations. To approach this group and establish a dialogue it could be useful to let the young people themselves define the problem and suggest preventive measures, as in a bottom-up perspective ${ }^{23}$. To take the keys from drivers who are drunk to prevent them from driving is one way that can prevent accidents.

In the preventive work, a specifically developed strategy targeted at those defined as high risk takers should supplement strategies targeted at the whole population and all groups of snowmobile drivers. A population strategy should contain a discussion of norms in and amongst those who drive snowmobiles, while a strategy to reduce high-risk activities should target behaviours such as the ones on which the police focus: drunk driving, driving off track and night driving. Night driving is not in itself illegal, but often involves party driving between holiday cabins and campsites and may include drunk drivers, who pose a great danger to themselves and to others.

\section{Risk precautions in snowmobiling and outdoor life in the north: external factors}

Snowmobile trips involve risks triggered by nature, terrain, vehicles and individuals' lack of knowledge or willingness to follow the recommendations for snowmobiling. External factors such as weather changes, reduced vision, snow cliffs, wind holes or risk of avalanches that arise during a snowmobile trip may challenge the driver to re-orient, reinterpret and re-calculate the risk. It is important that snowmobilers have education and training in being riskoriented and recognising risk situations, and that they are knowledgeable about outdoor activities. This is about interpreting the context by continuously assessing changing driving conditions like visibility, amount and type of snow, and terrain, as discussed in the fieldwork of Mehus and Germeten $^{22}$. Some of the informants in the present study mentioned external risks associated with weather conditions, terrain and pre-risk evaluations of the tracks. Local people designated to the task carry out pre-risk evaluation of the 
tracks every winter season prior to opening them. Following pre-risk-evaluated tracks helps drivers avoid dangerous areas with risks of avalanches, wind holes, water holes and crevasses. The informants state how they stop and mark dangers so that others following them on the trail will avoid these dangers. This demonstrates a type of awareness of risk and risk reduction, which is both responsible and preventive (Tables 2,3). One well-executed overall structural countermeasure is to mark the tracks well, and for the drivers to keep on the track, and not to be tempted to off -piste riding. The lack of marked tracks on Svalbard means that drivers continuously have to make risk assessments of the terrain, even when driving. When the authorities on Svalbard allow driving off-piste it puts a great responsibility for risk assessment relating to wind holes, cracks on glaciers and the danger of avalanches on the individual driver. One of the most important safety precautions is to stay on the track and follow the recommendations of Sy and $\operatorname{Corden}^{20}$ :

- Never drive alone or on unfamiliar ground.

- Drive on tracks.

- Avoid waterways and bad weather, areas with trees, fences and rocks.

- Take precautions at night.

- Slow down at the top of a hill, on cliffs or on snow banks.

- Always use helmets; wear well-insulated clothes.

- Towing a sledge or tube is dangerous.

- Always bring a first aid kit and mobile phone with you.

- Never drink while driving.

- Never allow children to drive.

Several informants identified staying on the tracks as an important factor in reducing accidents. Evaluations of external risks depend on individual skills and local knowledge. Snowmobile licence training courses should comprise local risk assessment and evaluation, as well as instructions to bring along a basic minimum of survival and safety equipment even on shorter trips. Driving and being out in the countryside and developing one's skills as a safe driver increase with experience, and young people learn which norms to follow and what to look out for with regard to risk.

As several respondents stated it is vital to be aware of weather conditions in the north, and particularly of changes in the weather, which may occur quickly in Arctic areas. According to research findings, it is very important to be able to interpret the terrain and driving conditions ${ }^{4,5,7,22}$.

\section{Practical implementation in community-based contexts}

Community-based injury prevention is important for society because it follows the fundamental principle of 'starting where people $\operatorname{are}^{\prime 23}$. In accident prevention work, it is also important to bring in other types of practical knowledge from outside groups, such as injury epidemiology, police reports and reports of undesirable events. This can create a balance between a bottom-up and a top-down perspective, where knowledge generated from fields both inside and outside the snowmobile environments is used to develop approaches to reducing accidents. This calls for a dialogue between experts and lay people. The balance between bottom-up and topdown perspectives can be situation-specific and dependent on snowmobilers' knowledge. The findings in this study suggest that young people themselves know and have experience with how and why accidents occur. In the eagerness to prevent accidents, one should also be aware that 'selling the snowmobile and lying on the sofa' and not be out with friends, not experiencing the freedom of being out in the countryside, or mental and physical challenges in everyday life, can also be a health threat. Research on young snowmobilers has reported that they experience going out on trips with friends as being good for their health, and as promoting a will to live and wellbeing ${ }^{4}$, which are important aspects of health promotion ${ }^{23}$. The Norwegian snowmobile licence education focuses on navigation, training, driving and risk assessment. In addition, it could target young people's driving and outdoor life skills, knowledge from research about what causes the accidents, vulnerability and in what context accidents often occur. 


\section{Table 3: Preventive strategies identified by study participants}

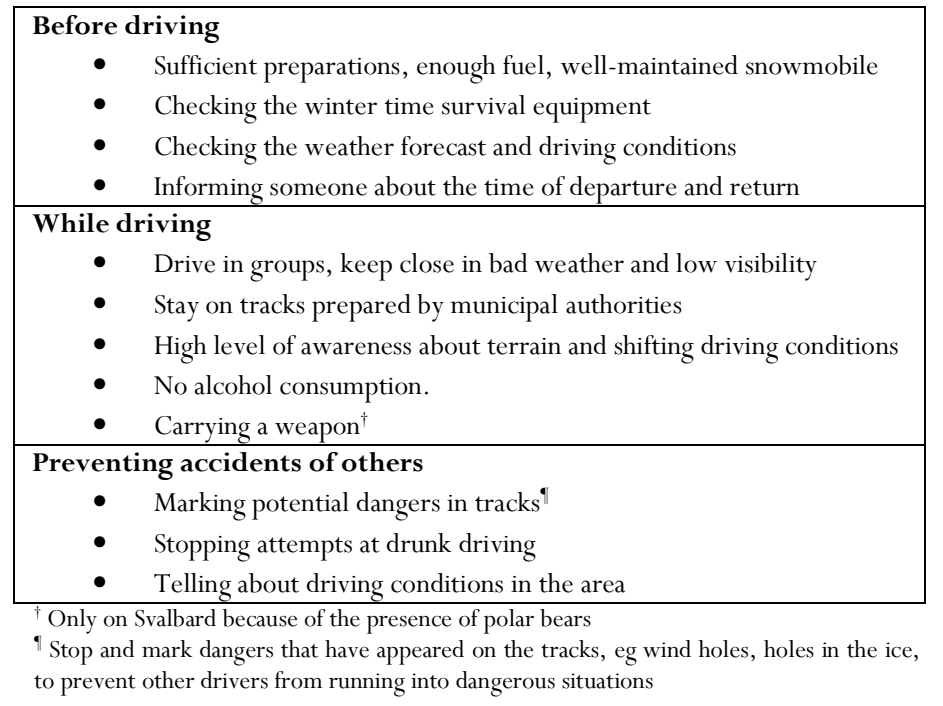

A strategy in a community-based education program is most effective when it is built around membership support, innovation and contribution ${ }^{23}$. The young people have to participate in setting the agenda, the goals and the measures based on what they define as important.

The police have to monitor designated subgroups, but they can also play an active part in snowmobile associations and schools, discussing norms and attitudes while highlighting the snowmobiling regulations they are there to enforce. A potential research project could test a problem-oriented police surveillance program for snowmobiles in Northern Norway, like the one carried out in Sudbury, Ontario in Canada, to see whether experiences are transferable across contexts when it comes to reducing undesirable driving behaviour, accidents and fatalities ${ }^{19}$.

Limitations to the present study stem from the self-selection of participants within a secondary school context, and the study results may therefore not be representative of all adolescent snowmobile drivers in this geographical area. However, encounters between snowmobilers are not restricted to one specific youth group, and stories narrated by the research participants may therefore reveal widespread attitudes and practices. Also, focus group participation has the potential to limit openness, as group members might control each other's stories regarding sensitive behaviours. It could well be that some statements exaggerate or downplay some aspects of incidents and reactions due to group dynamics. However, incidents of intra-group corrections or contesting others' statements rarely occurred, and this may be a sign of consensus regarding the content of the narratives.

Another limitation to the generalisability of the results is that this study is eight years old, and the informants no longer belong to the interviewed age cohort. Nonetheless, accidents still occur and similar practices are reported in media, including 'high marking' (snowmobiling as high as possible up a steep mountain), which has the risk of starting avalanches. Besides, knowledge in the field regarding individual and external risk factors has not changed significantly over the period. 


\section{Conclusions}

Narratives in this study reveal individual risk taking, how accidents occur, needs for education, and safety precautions taken before snowmobile trips. Young people's experiences and attitudes provide important knowledge for community-based injury prevention programs. Competent instructors who are also experienced snowmobilers should activate this knowledge in local educational contexts, for example by directing driver awareness towards pre-risk assessment, thus contributing to enhancing young people's driving skills. Infrastructure with planned and marked tracks and common safety recommendations are elements of external pre-risk assessment. Some parts of the risk assessment will always rely on the individual and will diverge from recommendations due to lack of knowledge, resources, practical experience and miscalculation.

Further research should be undertaken to explore the differences in attitudes between boys and girls, for example regarding whether experienced female drivers exhibit a driving behaviour more similar to the more experienced boys, or whether avoidance of risk is a gender-based phenomenon unaffected by development of driving skills and experience. Informal development, negotiations and regulation of norms within peer groups should be an indispensable theme in preventive strategies.

\section{Acknowledgements}

The authors are grateful to the principals of the secondary schools and to the young people, who showed a tremendous amount of trust in the interviewer by narrating their activities. Funding for this research was granted by the Research and Development Committee at the Finnmark University College.

\section{References}

1. Fylkesmannen i Finnmark [County Governor of Finnmark]. Snoscooter- og barmarksloyper i Finnmark - kart og GPS [Snowmobileand dryland tracks in Finnmark - maps and GPS]. (Internet) 2009. Available: http://www.nordatlas.no/default.aspx?gui=1\&lang =2\# (Accessed 24 April 2015).
2. Fylkesmannen i Troms [County Governor of Troms]. Snøscooterløyper i Troms. [Snowmobile tracks in Troms]. (Internet). Available: http://www.nordatlas.no/default.aspx?gui=1\&lang =2\# (Accessed 24 April 2015).

3. Statistics Norway. Registered motor vehicles. Snowmobiles. SSB no. 2013. Uttrekk fra det Sentrale Motorvognregister. Oslo. [Statistics ordered from Central Motor Registry, Norway], 31 December 2008

4. Mehus G, Germeten S, Henriksen N. Snøscooterkjøring og scooterfeelingen [Youth, snowmobiling and the 'snowmobile feeling']. Tidsskrift for ungdomsforskning [Journal of Youth Research] 2010; 10(2): 39-56. (Internet) 2010. Available: http://www. hioa.no/asset/6513/1/6513_1.pdf (Accessed 4 May 2016).

5. Mehus G, Germeten S, Henriksen N. How young people communicate risks of snowmobiling in Northern Norway: a focus group study. International Journal of Circumpolar Health 2011; 70(2): 205-214. http: / /dx.doi.org/10.3402/ijch.v70i2.17807

6. Hortemo GS, Brattebo G, Hellesnes S [The snowmobile - only for fun? Registration of snowmobile accidents in Western Finnmark 1988-89]. [Comment]. Tidsskrift for Den Norske Laegeforening Uournal of the Norwegian Medical Association] 1990; 110(10): 1196-1968.

7. Jeppesen E, Wisborg T. Skader fra bruk av snøscooter i VestFinnmark [Snowmobiles and serious injuries in Western Finnmark]. [Comment]. Tidsskrift for Den Norske Laegeforening Uournal of the Norwegian Medical Association] 2005; 125(23): 3248-3251.

8. Ytterstad B, Dahlberg T. Snøscooterskader på Svalbard [Snowmobile injuries on Svalbard]. [Comment]. Tidsskrift for Den Norske Laegeforening 2005; 125(23): 3252-3255.

9. Beirness DJ. Alcohol involvement in snowmobile operator fatalities in Canada. Canadian Journal of Public Health 2001; 92(5): 359-360.

10. Cattermole TJ. Snowmobile injuries in Antarctica 1989-1996. International Journal of Circumpolar Health 1997; 56(4): 152-158. 
11. Nayci A, Stavlo PL, Zarroug AE, Zietlow SP, Moir CR, Rodeberg DA. Snowmobile injuries in children and adolescents. Mayo Clinic Proceedings 2006; 81(1): 39-44. http://dx.doi.org/ $10.4065 / 81.1 .39$

12. Pierz JJ. Snowmobile injuries in North America. Clinical Orthopaedics \& Related Research 2003; (409): 29-36. http://dx. doi.org/10.1097/01.blo.0000057781.10364.c9

13. Rowe B, Milner R, Johnson C, Bota G. Snowmobile-related deaths in Ontario: a 5-year review. Canadian Medical Association Journal 1992; 146(2): 147-152.

14. Rowe B, Milner R, Johnson C, Bota G. The association of alcohol and night driving with fatal snowmobile trauma: a case-control study. [Comment]. Annals of Emergency Medicine 1994; 24(5): 842-848. http://dx.doi.org/10.1016/S0196-0644(94) 70202-0

15. Öström M, Eriksson A. Snowmobile fatalities aspects on preventive measures from a 25-year review. Accident Analysis \& Prevention 2002; 34(4): 563-568. http://dx.doi.org/10.1016/ S0001-4575(01)00057-4

16. Stewart RL, Black GB. Snowmobile trauma: 10 years' experience at Manitoba's tertiary trauma centre. [Comment]. Canadian Journal of Surgery 2004; 47(2): 90-94.

17. American Academy of Pediatrics. American Academy of Pediatrics. Committee on Injury and Poison Prevention. Snowmobiling hazards. Pediatrics 2000; 106(5): 1142-1144.

18. Bjørnstig U, Eriksson A, Valverius M. Fatale snöscooterulykker [Fatal snowmobile accidents]. Lakartidningen 1980; 77(16): 1547-1549.

19. Rowe BH, Therrien SA, Bretzlaff JA, Sahai VS, Nagarajan KV, Bota GW. The effect of a community-based police surveillance program on snowmobile injuries and deaths. Canadian Journal of Public Health 1998; 89(1): 57-61.
20. Sy ML, Corden TE. The perils of snowmobiling. Wisconsin Medical Society 2005; 104(2): 32-34.

21. Ministry of Health and Care Services. Accidents in Norway: strategy to prevent accidents and injuries in Norway. [Ulykker i Norge. Nasjonal strategi for forebygging av ulykker som medforer personskade 2009-2014]. Oslo: Ministry of Health and Care Services, 2009.

22. Mehus AG, Germeten S. Delrapport 2 i prosjektet 'Snoscooter og trafikksikkerhet'. [Second report in the project: snowmobiles and traffic safety. Field research in Norway]. (Internet) 2009. Available: http: / / munin.uit.no/bitstream/handle/10037/6207/Rapport\%2 02009-1. BRAGE.pdf? sequence $=1 \&$ isAllowed $=\mathrm{y}($ Accessed 1 May 2016).

23. Green J, Tones K. Health promotion: planning and strategies. Los Angeles: SAGE, 2010.

24. Berger P, Luckmann T. Social construction of reality: a treatise in the sociology of knowledge. London: Penguin, 1967.

25. Gofmann E. The presentation of self in everyday life. Harmonsworth: Penguin Books, 1971.

26. Morgan DL. Focus group interviewing. In: G Gubrium, G Jaber, JA Holstein (Eds) Handbook of interview research, context and method. Thousand Oaks: SAGE, 2001. http://dx.doi.org/ 10.4135/9781412973588.n10

27. Graneheim UH, Lundman B. Qualitative content analysis in nursing research: concepts, procedures and measures to achieve trustworthiness. Nurse Education Today 2003; 24(2): 105-112. http://dx.doi.org/10.1016/j.nedt.2003.10.001 